ly; all numbers in present couplets 6 to 9 inclusive are, therefore, increased by 2 to tie in with $\mathrm{I} 2$ and the remaincler of the key.

Page 57: in couplet 15 , the end number I9 should be 18 .

\title{
SEVENTH INTERNATIONAL, CONGRESS FOR ENTOMOLOGY BERLIN 1938 .
}

According to the resolution adopted by the Executive Committee for International Congresses for Entomology, the Seventh International Congress for Entomology will convene in Berlin, from August I5th to 2oth, I938.

Discussions will be held in the following sections and on the subjects indicated below :

A. General Entomology':

(I) Systematics and Zoogeography. (2) Nomenclature and Bibliography.

Morphology, Physiology, Embryology and Genetics. (4) Oecology.

B. Applied Entomology:

(I) Medical and Veterinary-medical Entomology. (2) Agriculture and Sericulture. (3) Forest Entomology. (4) Agricultural Entomology (a) Viticulture and pomiculture. (b) Agriculture and olericulture. (c) Pests. (5) Means and methods for fighting pests.

The Management of the Congress would deeply appreciate the participation of numerous representatives of scientific and practical entomology in the Congress to be convened in Berlin.

All entries for participation, and all inquiries, should be addressed to the Secretary General, Professor Dr. I-Tering, Invalidenstrasse 43, Berlin N. 4.

RESEARCH NOTES.

DISCOVERY OF AN AUTUMN HOST PI,ANT OF MYZUS PERSICAE SULZER,

During the past three years an annual increase in the numbers of Myzus persicae Sulzer on potato has been noted in one portion of New Brunswick. The aphids have left the potato plants in September but until this year (I937) it was not know to what plants they migrated in this region. A search made between September 8 and II in the potato-growing section of Carleton county, New Brunswick between Woodstock and Florenceville, resulted in the discovery of the alate (fall migrants) feeding and rearing young on the foliage of Prunus pennsylvanica $\mathrm{L}$. and $P$. virginiana $\mathrm{L}$.

J. C. BURNHAM.

Dominion Entomological Laboratory Fredericton, N. B.

\section{NEWS AND VIEWS}

DR. P. N. ANNAND TO BE RESEARCH ASSISTANT TO THE CHIEF OF THE BUREAU OF ENTOMOLOGY AND PLANT QUARANTINE, CNITED STATES DEPARTMENT OF AGRICULTTRE.

A recent press release from Washington informs us, that, effective September 7 th, Dr. P. N. Annand will be Special Research Assistant to the Chief of the Bureau of Entomology and Plant Quarantine, U. S. Department of Agriculture, and that Mr. C. M. Packard will succeed him as Chief of the Division of 
Cereal and Forage Insect Investigations. This announcement was made by Lee A. Strong, Chief of the Bureau.

Unhampered by administrative duties, Doctor Annand will devote his entire time to unifying the Bureau's research and making it more effective. This research, Mr. Strong points out, covers a very wide and constantly growing field. Divided among twelve subject matter divisions, it deals with insects and their relation to man, animals, and crops. Effective control measures for insect pests must be based on exact information on the way the insect looks and lives and on its relations to its hosts. This calls for knowledge of the hosts and their habits and extends into chemistry as it pertains to the developing of insecticides. Central planning is essential in getting the most out of this research.

Doctor Annand has been with the Bureau of Entomology and Plant Quarantine since July 3, I929. He first investigated the sugar beet leafhopper. 'Then he was assistant to the Chief of the Division of Truck Crop and Garden Investigations. Since January I6, I934, he has been Chief of the Division of Cereal and Forage Insect Investigations. Doctor Annand was born in Colorado. He holds the degree of ,Bachelor of Science from Colorado Agricultural College and the degree of Master of Arts and Doctor of Philosophy from Stanford University.

Mr. Packard a member of the Bureau since 1913, has been in charge of the laboratory of the Division of Cereal and Forage Insect Investigations at Lafayette, Ind. He directed and planned much of the investigational work, notably that on the Hessian fly and chinch bug, in this area. Mr. Packard was born in Massachusetts. The Massachusetts Agricultural College gave him the degree of Bachelor of Science; the University of California, the degree of Master of Science.

HESSIAN FLY INFESTATIONS LOW IN WINTER WHEAT BELT BUT UNUSUALLY NUMEROUS IN SOME NORTHERN AREAS OF 'THE UNTTED STATES

The hessian fly-No. I insect enemy of wheat--is about as scarce in the main winter-wheat areas of central and eastern United States as it ever becomes. The U. S. Department of Agriculture's annual fall survey shows extremely light fly infestations, with practically no signs of crop damage, in Nebraska, Kansas, and Oklahoma.

Flies are scarce generally in Iowa, Missouri, northern Illinois, central and northeastern Indiana, Ohio, Kentucky, Tennessee, western and central Pennsylvania, Maryland, Delaware, Virginia, and North Carolina, though occassional local infestations there may be a source of trouble next year. This low level in Hessian fly numbers, the Bureau of Entomology and Plant Quarantine says, results from the weather last fall, which was unfavorable to the flies, and to the delayed sowing of the 1937 wheat crop until after the adults had laid their eggs and died.

In some northern areas-notably northeastern Iowa, southern Wisconsin, and south central Michigan-hessian flies are unusually numerous, and southern Illinois, northwestern and southern Indiana, and southeastern Pennsylvania have moderate-to-severe infestations-the danger signal of a bad outbreak next year if weather favors the flies. 
With the results of the Department's survey, State of ficials concerned are warning farmers of the hessian fly threat and informing them of the safe-sowing dates, which vary from year to year and from locality to locality. This year they range from September 20 in the more northern areas to October 20 in the more. southern ones.

\section{ANNUAL MEE'TING ENTOMOLOGICAL SOCIETY OF ONTARIO.}

The Seventy-fourth Annual Meeting of the Entomological Society of Ontario will be held in the Royal Ontario Museum, Toronto, on Thursday and Friday, November I8th and I9th, 1937.

All those interested are urged to make an effort to be present, and help to make the meetings a success either by presenting a paper or taking part in the discussion. Please note that the mcetings are being held during the Royal Winter Fair thus affording an excellent opportunity to attend both events and to take advantage of the reduced fares offered by the railroads.

The presentation of a paper should not exceed I 5 minutes. This limit, however, does not apply to the manuscript. All those presenting papers are requested to prepare an abstract for delivery at the meetings, thereby allowing time for discussion.

Titles of papers should be in the hands of the Local Secretary by November Ist. Please advise if lantern is required.

The Annual Council Meeting will be held in the Royal York Hotel, Wednesday Evening, November I7th, at 8.I5 p.m., in private dining room No. 6.

Thursday Evening, November I8th, there will be an Entomological Dinner (the hour and place to be announced at the General Meetings) at which Professor Parrott of the Geneva Agricultural Experiment Station, will speak on his recent trip to South Africa, illustrated by motion pictures.

Hotel reservations may be made through the I,ocal Secretary.

President, I. S. McLaine,

Entomological Branch,

Secretary, R. H. Ozburn,

O. A. College, Guelph.

Department of Agriculture, Ottawa.

LOCAL COMMITTES:

J. R. Dymond, Royal Ontario Museum, Chairman; Dr. E. M. Walker, Dept. of Biology, Univ. of Toronto; Dr. F. P. Ide, Dept. of Biology, Univ. of Toronto; W. A. Fowler, Secretary; Plant Inspection Office, Room 549, Customs Bldg., Front and Yonge Sts., Toronto (2).

Mailed, October I6th, I937. 